\title{
IS RUSSIA THAT POWERFUL IN HYBRID WARFARE?
}

\author{
Tomiță Cătălin TOMESCU \\ “Nicolae Bălcescu" Land Forces Academy, Sibiu, Romania \\ cata.tomescu@gmail.com
}

\begin{abstract}
Short answer is yes. As it is stated in a NATO reference hybrid warfare actions can be applied to the full DIMEFIL (Diplomatic, Information, Military, Economic, Financial, Intelligence, Legal) spectrum. This paper will demonstrate that Russia has significant elements which makes this country very well suited for this type of war and gives her some advantages on all DIMEFIL areas. In my view those elements are: current leadership, history and political mentality, size and geography, economic and financial power and military power.
\end{abstract}

Keywords: hybrid warfare, military power, economic, finance, resources, history and mentality

\section{Introduction}

"We do not intend, as some do, to walk and waved the sword in the world. But all must understand that we also have something like that in our arsenal" President Putin 2014[1]

I started writing this article just after observing the attitude of Russia towards what happened in Syria on the $6^{\text {th }}$ of April, when the Syrian regime launched a chemical attack on their 'opponents'. I decided to put on paper some of my thoughts. This is not about denying Kremlin's intentions, also it is not my intention to clarify the hybrid warfare concept, neither to argue on different views on that, nor to develop the discussion over NATO's capacities. My purpose is to prove that Russia is very good on such kind of warfare because is very well fitted for that, and using hybrid warfare mechanisms can challenge NATO in his own courtyard and outside of this in places such as: Syria, Arctic area, Mediterranean, Black and Baltic Seas, and in organizations such as United Nations, OSCE (Organization for
Security and Cooperation in Europe), CSTO (Collective Security Treaty Organization), or SCO (Shanghai Cooperation Organization) formats. Actually they have already started doing that.

In theWarsaw Summit Communiqué (2016) it is stated that: "Russia's destabilizing actions and policies include: the ongoing illegal and illegitimate annexation of Crimea,... the violation of sovereign borders by force; the deliberate destabilization of eastern Ukraine; largescale snap exercises contrary to the spirit of the Vienna Document, and provocative military activities near NATO borders, including in the Baltic and Black Sea regions and the Eastern Mediterranean; it's irresponsible and aggressive nuclear rhetoric,.... and its repeated violations of NATO Allied airspace. In addition, Russia's military intervention, significant military presence and support for the regime in Syria, and its use of its military presence in the Black Sea to project power into the Eastern Mediterranean have posed further 
risks and challenges for the security of Allies and others"[2], and I think that is self-explanatory.

At the end, I expect that those who still think that the actual Russian leadership's strategic objectives are not so dangerous and NATO is overreacting by tacking serious response measures, to reassess their position and way of thinking. I agreed with col. Mastriano when he stated that: "NATO nations have divergent views of how to contend with the aggressive Russian approach. The nations near Russia seek assurance and deterrence measures, while those further away often call for moderation. Yet, the notion that accommodation will reduce the threat is viewed more in hope than reality. Of this Winston Churchill brilliantly said, "The appeaser feeds the crocodile hopping that it will eat him last." The U.S. and its NATO Allies have hard decisions to make. Will it take sufficient action to deter further Russian aggression? Or, will the nations deliberate and delay action until it is too late?"'[3].

The biggest danger is to wait until Russians will 'knock out' at their door. In my view Europe should prove solidarity and cohesion first of all on itself and then under NATO format. I'm confident that after the last 100 years of common history Europe cannot be cheated anymore by Russia. Do not forget cheating is part of the game in hybrid warfare ... and not only. To sustain this point I will quote James Nixey "Obama has been let down by Putin too many times and, like Merkel, has become disillusioned. The biggest failing, however, has been the self-delusion of expectations. Too much was invested in the 'Reset' and there was no contingency plan"[4]. There are contingency plans but the problem is that they do not solve the problem between NATO and Russia, they just keep it away on do not recognizing that there a hybrid warfare type of conflicts started and is evolving.

\section{About hybrid warfare concept}

Dr. John Lennox, a professor of Oxford University, says "New things are old things happening to new people" [5]

In order to have a better understanding of the subject I will present some considerations on hybrid warfare, but first what does it means? Difficult to say, there are many point of views in the analysts and researchers family throughout the world, but I will present to you one of the best definitions, coming from a NATO reference I discovered in a NMSG Conference held in Bucharest in 2016: "Hybrid Warfare is underpinned by comprehensive hybrid strategies based on a broad, complex, adaptive and often highly integrated combination of conventional and unconventional means, overt and covert activities, by military, paramilitary, irregular and civilian actors, which are targeted to achieve (geo)political and strategic objectives. They are directed at an adversary's vulnerabilities, focused on complicating decision making and conducted across the full DIMEFIL spectrum in order to create ambiguity and denial. Hybrid strategies can be applied by both state and non-state actors, through different models of engagement, which may vary significantly in sophistication and complexity. Adversaries employing hybrid strategies will seek to remain ambiguous, claim pursuit of legitimate goals and aim to keep their activities below a threshold that results in a coordinated response from the international community. This includes avoiding direct military confrontation, if possible; although the use of overt military action as part of a hybrid strategy cannot be discounted"[6].

There could be many other definitions on the subject and also many scientists and researchers could disagree with this concept, but I suggest you keep in mind this one as a reference used to demonstrate and sustain my arguments about Russia. As we can see the hybrid type of actions could be used in the entire DIMEFIL structure by 
both state and non-state actors. Here, I would argue with the composition of the spectrum and I will add the social and political field which, in my opinion, must be part of it. In the social field might be included all the issues related to the population of the targeted state such as ethnic and religious composition. Best example is the way how Crimea was taken under Russian control just by using Russian ethnics vote, or how Moscow managed to put pressure on Moldova using an old frozen conflict, namely in Transnistrian province, as well as in Georgia or Baltic states using the same entity. Does the political field need an argument? Diplomacy itself is just a tool of the political domain. Everything in our days is about political decisions and nothing can happen without them. Lastly, all conflicts have always had significant outcomes, first of all, in political and social fields. But this could be a very good subject for another article so, I will stop here and I will continue with the hybrid warfare characteristics.

Many analysts and researchers, after the events in Ukraine argue that Russia applied hybrid warfare type of action in order to take Crimea and to help the separatists from Donbas region. So, the question is why hybrid?

Probably because this type of action allows the promoter to achieve strategic political objectives a lot easier and cheaper than a regular warfare. Another reason would be that these types of actions are effective when the promoter cannot afford to engage the targeted country or organization in a direct conflict conducted under classical war premises. Also hybrid strategies and actions are very effective against an Alliance such as NATO, a point sustained also by same Turkish specialists in the area: "The use of hybrid strategies in conflict are not new, but what is new for NATO is the way a wide range of political, civil and military instruments are combined and coherently applied, aiming at particular vulnerabilities of targeted nations and international organizations in order to achieve strategic objectives ...... Increasingly sophisticated cyber-attacks, far reaching complex propaganda and misinformation campaigns, as well as targeted and coordinated political and economic pressure are indicative of modern hybrid warfare scenarios, ... Furthermore, hybrid strategies aim at complicating, delaying and impeding timely decision making and undermining the ability of an Ally or the Alliance as a whole to respond to such a threat swiftly, firmly and effectively"[7].They are effective mainly because it is very difficult to prove who did it and even more difficult to be legally accounted for by the international community. Best examples are provided by Russia`s actions in Ukraine and more recently in Syria.

Why is Russia, in order to achieve its strategic objectives, using this type of warfare? My short answer to this question would be: because it is very well suited for this. Furthermore I would add that this country has a lot of mechanisms to manage the process such as: political, social (offered by frozen conflict areas, historical background and the use of Russian ethnics) and economical pressure over a large number of European states, and of course enough military power to engage any country in Europe if the situation gets worse.

In this sense, the next question would be what makes Russia very well fitted for the hybrid warfare? From my point of view there are several reasons of which I will present, not making a hierarchy, five of them as it follows: size and geography, combat power, energy and financial resources, history and mentality and the actual leadership.

\section{Why is Russia that powerful in hybrid warfare? \\ "I cannot forecast to you the action of} Russia. It is a riddle wrapped in a mystery inside an enigma; but perhaps there is a 
key. That key is Russian national interest" $[8]$

Winston Churchill, October 1, 1939

First argument is the size and geography. Russia is the largest country on Earth and because of its position Russians are neighbors with everybody important in the Northern hemisphere. This situation allows Russia to easily interfere in European and Arctic continents, Caucasus and Central Asia, Atlantic and Pacific oceans and nonetheless on the Arctic Sea routes. Also that creates significant advantages on the trade of energy resources and on the military actions scheme of maneuver, by having the facilities to conduct direct ground operations without significant strategic mobility requirements. This geography also imposed Russia as a very important political and economic player in Eurasia. In this sense James Nixey said: "Putin's Eurasian Union is still a long way from becoming a real political entity....The alliance evolved from a straightforward customs union in 2005 to a Eurasian customs union in 2010, becoming the Eurasian Economic Union in 2015 - all useful economic preliminary steps towards a full - i.e. political - Eurasian Union. This, finally, is intended to provide Russia with the instruments for control in creating an alternative pole to the EU-centric order. Eurasianism provides the ideological glue and Russia, of course, is the self-appointed head of the Eurasian civilization. The concept of Novorossiya is an ideological extension and historical justification of this project," [9].

In addition, size provides to Russia huge and divers resource stock which in the future will constitute a fundamental advantage. Connecting those elements with DIMEFIL we can observe that they grant significant capabilities at least on the political, diplomatic, military, economic and financial domains.

Second one is the combat power. Keeping aside the nuclear capability that provides to Russia a strong deterrence posture, which is often used when they want to close a subject, this country has a substantial conventional military power. In some areas such as tanks, air power, A 2 AD (Anti Access and Area Denial), special and airmobile forces, cyber and submarines Russia is at the top level along with the other military powers. Recently (after involvement of Russia in Ukraine and Syria) Russia is developing a strong A 2 $\mathrm{AD}$ belt in order to protect its Western boundaries against NATO. Moreover, I would say that even though Russia has just a single air-carrier (which is old and the pilots do not prove as much capability as they expected to in recent action in Syria), they have created three "ground aircarriers" in order to control Baltic Sea (via Kaliningrad), Black Sea (via Crimea) and Eastern Mediterranean (via Latakia and Tartus bases in Syria). Moreover, as col Mastriano observes: "It may be just this that is in the back of Putin's mind with his stunning announcement to modernize and expand Russian's nuclear arsenal and armed forces. In just few years, Moscow will have both a modernized conventional ground force and robust unconventional force, backed by a large nuclear arsenal" [10] and those specific Russian actions, do threaten the countries located in the Eastern NATO border. We can observe that Russian military system offers to Kremlin`s leadership significant capabilities to maneuver a targeted state on all DIMEFIL areas including political and social domains.

The third one is the economic and financial power. The power in these areas is given by the significant amount of strategic energy resources such as gas and oil and also by the constant rise, in last decade, of the military equipment sales. According to the Russian approach "gas means power and oil means money", and those key words were successfully used by Moscow when dealing business or doing politics with some European and Asian countries (some of them very important ones, members or not 
of NATO). As we all know all main important gas and oil pipelines are going from Russia to Europe and in return the money goes from Europe to this country and by that everything is explained. But that means also that Russia is depending on Europeans as Mr. Nixey shows: "Yet the Kremlin well knows that it is economically and culturally bound to Europe, still the destination for 48 per cent of Russia's trade, 78 per cent of its tourists and 80 per cent of its pipelines"[11] and because of that at least the good relations must be kept. In addition to that I would like to take into consideration the significant military industrial complex that Russia has. With respect to this it is important to be mentioned that Russia it was the third largest exporter of military equipment after US and France (in 2015) as it is presented on The Guardian in Dec 2016[12]. That means a lot of money and creates an important military and political connectivity with the ones which buy them and nevertheless provides required financial resources in order to develop Russian military power. Going back to DIMEFIL we can observe that those elements offers to Russia important strategic advantages at least on military, economic and financial fields.

The fourth important argument is the history and mentality. On this subject there are written books and articles starting with Peter the Great period to our days. Essentially Russian leadership always considered as normal to control from Moscow its smaller neighbors (especially former soviet states) and here is the concept, as Ambassador Lyne stated:"In the Russian view, these states are a greater or lesser extent historically part of Russia, acquired independence accidentally rather than through a formal settlement of the post-Cold War order, are intimately linked to Russia through myriad personal and economic connections, and form Russia's security perimeter. They must therefore be recognized as within Russia's 'sphere of strategic interests', and must not be permitted to act in ways or form affiliations that are deemed to be contrary to Russia's strategic interests",[13].

Always this political objective was in the forefront of Russia's foreign policy and especially in the last century since the communist era started. Even in our days they expect to control and influence most of the countries in their vicinity in Europe and Central Asia.

Last 70 years proves also that Moscow never paid a great respect for all other smaller European countries located between former USSR and Germany. Even now there are criticisms regarding the 'expansion' of NATO towards East. Amazing how after 27 years, since the fall of communism and disintegration of Warsaw Pact it is not clear that all those countries, after 1989, applied for EU and NATO membership because they wanted to be far from the Eastern type of democracy which they already know. Furthermore, why such a great problem from Kremlin when none of them can represent a threat for Russia, so where is the issue?

In that old mentality of course which is very difficult to fight with. However, this problem will disappear only after some generations when nobody will remember about the communist era in Europe. Until then it is clear that in our days a significant part of Russian leadership and politicians are strongly influenced in their political, diplomatic and economic decisions by the past which is the origin of their 'hybrid' mentality.

The fifth, and the most important argument, is the actual Kremlin leader mentality and personality. For me, President Putin is the most important factor, among the others presented above, for one big reason: it is the only one which changed over the years, most of the others four arguments having remained stable. His strong personality launched him as the strong man in Russia 
and since 2002, he proved that to his nation over the years. First mandate of his and during President Medvedev, he was busy consolidating his power internally, but in the last decade President Putin leadership makes the difference on Eurasian political arena.

There are very good results on political area and financial indicators, but also are many others, especially internal problems, which are going wrong. Here might be mentioned the high level of corruption, low demography, low life expectancy rate, depopulation of rural areas, big suicide rate, decline of the economical products (out of exporting oil and gas) and social inequalities. At the end what will happen with Russia when he will be over?

But those are his problems and going back to the subject I would say that out of his strong personality, 'forever young' sport attitude and popular character, his power is coming from the fact that he has something which most of the other world leaders do not poses, and this is the hybrid warfare mentality. He was born and raised on hybrid warfare type of actions through KGB service and education. This war becomes evident and it was developed during Cold War period and since then he just applied it because it was his job. He doesn't need somebody to explain to him about that because he already knows everything. Moreover he is the one who gives orders and guidelines and the others are listening and executing.

Being armed with such skills, President Putin challenged EU and NATO unity and resolve while he simultaneously developed strong partnerships all over the world, especially in the Eurasian region. $\mathrm{He}$ skillfully identified all individual political weaknesses or misunderstandings at the EU and NATO level and capitalizes on them to his advantage. In short, in political field, Russia is about to regain a global status which make Moscow a mandatory stop in our days. Putting aside global victories I will direct your attention to some European facts. As Mr. Nixey observes: "Others in Europe are even less embarrassed in their support for the Russian leadership's course of action. In June 2014, for example, Putin received red-carpet treatment in Austria, where Moscow has extensive networks; and he got a hero's welcome in Belgrade and Budapest in late 2014 and early 2015 respectively"[14].

If the approach to Belgrade might be explained by the events that happened in Western Balkans between1994-1999, the friendship with Budapest looks strange. Officially they discussed about strengthening economic relations but 'what if they discussed over the future of the Hungarian aspirations concerning them minorities located mainly in neighboring countries from Central Europe. As everybody knows, periodically, Hungarian leadership agitates the Hungarian minorities spread across the countries of Central Europe, sometimes creating internal problems or diplomatic incidents. Adding to this the control over the Black Sea by Crimea, Baltic Sea by Kaliningrad, Georgia by Abkhazia and Ossetia, Moldova by Transnistrian territory, Baltic countries by Russian minorities, Western Balkans by Serbia, East Mediterranean Sea by Syria we can identify a large hybrid warfare mechanism ready to function if necessary.

I will conclude that President Putin personality and skills makes him a powerful STRATCOM player and an even more powerful infoops manager. As everybody observed most of the time Russian leadership take the lead on STRATCOM and NATO or EU most of the time are reacting to that and also in most diplomatic issues Russia is getting out as 'white' as the pure milk. Also he is a bright user of all four tools, presented above, that Russia has at his hand in order to regain the position they had in Cold War period even though that it will be hardly difficult in the new post - Cold War era environment. And that is a reality because out of the US many 
other players shows up and they want them slice from the global power.

\section{Way ahead}

"The question is: will Russia hold?!?"[15]

Should NATO engage with Russia on his hybrid warfare style? The Alliance answer was diplomatic and peaceful but firm, as it was approved at the Warsaw Summit in 2016: "As we agreed at our Wales Summit, we will continue our strategic discussion on Euro-Atlantic security and our approach to Russia. As we also agreed at Wales, we continue to believe that a partnership between NATO and Russia ....would be of strategic value. We regret that despite repeated calls by Allies and the international community since 2014 for Russia to change course, the conditions for that relationship do not currently exist. The nature of the Alliance's relations with Russia and aspirations for partnership will be contingent on a clear, constructive change in Russia's actions that demonstrates compliance with international law and its international obligations and responsibilities. Until then, we cannot return to "business as usual"[16].

Until now, surprisingly Russia is responding by duplicating his efforts in Europe and in Middle East (Syria). If negotiations and attempts to return to "business as usual" fail, looks like we are going to a new Cold War period. What can the Alliance do in such circumstances? Out of military superiority the Alliance already asked for solidarity and cohesion in both NATO Summits in Wales (2014) and Poland (2016).
This is on the solidarity and cohesion subject which I want to address. Probably there are some members which consider that this hybrid warfare is threatening only the countries at the Eastern border of NATO. If so, I think this might be a very "speedy" conclusion taken very fast and I would recommend they ask themselves "what if?".The events, related to Russia, that occurred in the post - Cold War era, prove that the prevision of the Washington treaty in Article 5 remain not only valid but necessary and mandatory in order to protect ourselves successfully against any threat.

At the same time, let's hope Russia will realize that time is working in favor of the Alliance and Kremlin will avoid escalating the present situation. I recall from one of my article wrote in 2014 that: "During Gorbachev's, USSR gave up the arms race just because it could not sustain the economical and financially effort ... Currently, the significant internal problems of social, economic and demographic faced for a few years by Russia might no longer be possible to be "kept under blanket", and so Kremlin could be forced to change the direction of political and economic effort from outside on the inside". [17] I hope that President Putin, before the end of his career will understand that the future of his beloved country is more important than the present. Moreover, if Russia wants to have a bright future that must be only along with European and Euro-Atlantic partners facing together the unexpected threats which surely will come up till the end of this century.

\section{References}

[1] Tomescu, T.C., "The influence of the crisis in Ukraine on the strategic political-military directions set at the Alliance's Summit in Wales in 2014 and of the NATO - Russia relation", Land Forces Academy's Review, vol. XX, No 1 (77), Q1, 2015, p 26

[2] Warsaw Summit Communique, art. 10, p. 3

[3] Col Mastriano, D., PHD, (Collective of authors), Project 1721: A U.S. Army War College Assessment on Russian Strategy in Eastern Europe and Recommendations on How to Leverage Landpower to Maintain the Peace, Strategic Studies Institute of the U.S. Army War College 2016, p. xi 
[4] J. Nixey, J.and all, Chatham House Report, "The Russian Challenge", The Royal Institute of International Affairs, June 2015, p. 38

[5] Col Mastriano, D., cit.ed., p. x-xi

[6] E. Çayırc1 and all, Presentation on Modeling and Simulation for Hybrid Environments, at NMSG Conference, Bucharest, Oct 21-22, 2016

[7] Ibidem

[8] Col Mastriano, D., p. ix

[9]J. Nixey and all, cit.ed., p. 35

[10] Col Mastriano, D., cit.ed., p. 23

[11] Nixey, J. and all, cit.ed., p. 36

[12] Helmore, E., "US increased weapons sales in 2015 despite slight drop in global arms trade", The Guardian, Dec 26, 2016

[13] Lyne, R. and all, Chatam House Report, p. 7

[14] Nixey, J. and all, cit.ed., p. 37

[15] Tomescu, T.C., cit.ed., p. 27

[16] Warsaw Summit Communique, art. 15, 3-4

[17] Tomescu, T.C., cit.ed., p. 27 